MedieKultur | Journal of media and communication research | ISSN 1901-9726

Article - Theme section

\title{
"If you don't act, you are not going to get anything" \\ Professional identity and gender equality \\ in Greek and Cypriot media organisations
}

\section{Angeliki Gazi and Dimitra Dimitrakopoulou}

MedieKultur 2016, 93-115

Published by SMID | Society of Media researchers In Denmark | www.smid.dk The online version of this text can be found open access at www.mediekultur.dk

\begin{abstract}
The research here focuses on the relationship between women and media organisations in Greece and Cyprus. Our aim is to study the professional identity of women in the context of media organisations as well as the progress toward gender equality in Greek and Cypriot media organisations compared to the rest of Europe. Greece and, to a greater extent, Cyprus are societies in which the preservation and reproduction of the structure of the family constitutes the primary mechanism for socialization and professional accomplishment, much more than in other countries of central and northern Europe. The reported results are part of a more broadly focused EIGE Report entitled "Advancing gender equality in decision-making in media organizations," which reviews the implementation of the Beijing Platform for Action (BPfA) in Member States. The BPfA, in turn, introduces the first indicators for measuring the progress of gender equality for women in the media. The media sectors both in Greece and Cyprus continue to be male-dominated. Women occupy only a small percentage of decision-making posts in media organisations. Moreover, there is a significant lack of gender-related policies and monitoring mechanisms in the media organisations and the countries themselves.
\end{abstract}

\section{Keywords}

professional identity, media organisations, policies, gender equality 


\section{Gender and Professional Identity}

The present paper addresses the issue of gender inequality in the media sector, drawing on the cases studies of Greece and Cyprus, two countries in South-East Europe, members of the EU and both sharing significant national characteristics (with the prominence of a common language). The data were collected during a pioneering research project entitled "Advancing gender equality in decision-making in media organisations. Review of the implementation of the Beijing Platform for Action in the EU Member States", commissioned by the European Institute for Gender Equality and conducted in the $27 \mathrm{EU}$ member states and Croatia. ${ }^{2}$ The project was conducted in these countries over six months and aspires to contribute to the exploration of the media landscape with regard to the participation of women in high managerial positions as well as to review available gender-equality policies and practices. In the following, we start our literature review by focusing on organisational theory and professional identity and then proceed with a description of the sociocultural characteristics of Greece and Cyprus to provide an operational context for the analysis of our case studies. In the second part of our paper, we continue with the methodological framework of our study and then we elaborate on our data deriving from the research conducted in Greece and Cyprus.

\section{Approaching organisations and professional identity}

In 1955, Elliot Jacques defined organisations as unconscious mechanical systems set against paranoid and depressive anxiety; thus, he came to be regarded as one of the founders of the socio-psychoanalytical School of London, whose contribution to highlighting unconscious collective powers and conflicts as constituent parts of social life has been immense. From the 1970s onward, the prevalence of one approach to organisational theory was reversed, and disagreement over the dominance of different tendencies in the wider landscape of social theory ensued.

During the 1970s, two trends with respect to studying organisations can be distinguished. The first one seems to signal a turn toward a more rational and economic approach to the way organisations function, while the second one follows the assumptions of hermeneutics. Hermeneutics encompasses the attribution of symbolic meaning to the acts of members of an organisation and tries to investigate the effects of culture on the everyday practices of organisations (Panagiotopoulou, 1997). One way to approaching a subject's identity through hermeneutics is to ask: How do persons behave in the context of organisations? (Strati, 1989; Witkin, 1989). According to Pages (1994), an organisation houses the context of work relations and, consequently, is responsible for the personal and social identities of its members.

The term professional identity refers to the identity developed in the context of an organisation. Barus-Michel (1997) links professional identity to activities with an achieved social status, such as work. In this context, organisations provide certain privileged items, 
surrogates for psychological objects. On one hand, the organisation is aware of the agenda and evaluates what must and must not be transmitted to the audience; on the other hand, it affects the professional development of its employees. Based on the theory of administrative behaviour, the subject imposes limits on his/her rationality from the moment he/ she belongs to groups that influence his/her value system (Van Yperen \& Van de Vliert, 2007). Social groups mediate the information received by the subject while, at the same time, they define the subject's relationship with other groups; they also have certain sociocultural characteristics, such as gender. A useful example that showcases the rules and norms of the management of groups in the context of media organisations is one that refers to the relationship between columnists and page-layout designers. Male designers may act more forcefully when making decisions compared to female columnists, although they do not necessarily have a good grasp of journalism. One of the reasons this happens is that men are more comfortable working with other men and, thus, find fertile ground for dominance (Marcellus, 2005). There are examples of men who describe their image and role in the organisation by saying that they feel "less comfortable" collaborating with female colleagues. (Gill, 2007, pp. 10-11).

An equally noteworthy opinion is shared by Simon (1958), March and Simon (1958) and Crozier $(1963,1970)$, who posit that the power a group possesses is the result of the uncertainty it causes to another team through dominance, through the exercise of control. Every group tries to expand the zone of uncertainty under its control while, at the same time, avoiding the sharing of information it possesses without giving something in return; instead, the group negotiates the disclosure of information in exchange for access to more information (i.e., to other sources of power) or demands some other concession. For instance, although women formed the majority of Canadian media organisation employees in 1995, most worked as reporters, and their careers stagnated (EIGE, 2013). In several countries, women face many difficulties in their attempts to penetrate media organisations, and some important reasons for this are gender discrimination in task allocation and the lack of support mechanisms for working mothers. Directors and boards can influence task allocation through decisions made inside the organisation. Interpersonal interactions and the relationships that managerial groups form with employees affect the effectiveness of the organisation (Van Yperen \& Van de Vliers, 2007).

The successful fulfilment of the goals and needs of the organisation depends on the decision- and policy-making centres within that organisation. According to Van Yperen \& Van de Vliert (2007), leadership is a process of social influence. During this process, board members may affect the behaviour and relationships between people who work in the organisation. However, it would be biased to suppose that an increase in the number of women at the highest level of the workplace hierarchy would contribute to a more beneficial working environment. In spite of all that, the media reflect the structure of society, and the fact that men are regarded as dominant in important and 'so-called "serious" professions' seems to be reflected in media organizations as well. From a sample of 25,000 Har- 
vard MBA graduates, according to research by Ely, Stone, \& Ammerman (2014), men are more likely to hold senior management positions associated with profit-and-loss responsibility and to have employees under their direct supervision.

\section{Are media organisations gender-sensitive? An overview of the evolution of the media landscape}

Whereas the field of media organisational studies emerged more than 50 years ago, it is only in the last few years that research has started to focus on the field of gender and the media (de Bruin, 2000). As Ross \& Carter (2011) note, feminist researchers have regularly argued that journalistic decisions on newsworthiness are greatly influenced by male conceptions of the world. Studies that focus on professional practices in journalism highlight that newsrooms remain deeply gendered (Carter et al., 1998; de Bruin, 2000; Byerly, 2004; Djerf-Pierre, 2005; Allan, 2010). This osmosis ${ }^{3}$ is so deeply rooted in the profession that, as de Bruin and Ross (2004) indicate, professionalised 'norms' in which gender differences are almost invisible are taken for granted and shape journalistic routines, conventions and norms in ways that make them difficult to identify as gendered and, therefore, difficult to challenge.

Traditionally, journalism is just one of many professions dominated by men; and, even though this trend is being challenged, recent research indicates that gender-related differences in work allocation persist (Gill, 2007). In theory, departmental managers at newspapers may have equal opportunities at the policy formation level, but statistics show that, when it comes to decision-making positions, men appear to outnumber female employees to a great extent. This was reported in the survey conducted by the International Federation of Journalists (IFJ) back in 2001, which found that women represented 40 per cent of journalists in newsrooms but just three percent were assigned to decision-making posts. A more recent study, a Global Report on the Status of Women in the News Media, demonstrates similar results, indicating that men hold 75 percent of top managerial positions, while women tend to work mainly in news-gathering roles and technical posts (Byerly, 2011). The Global Media Monitoring Project (GMMP) (WACC, 2005, 2010), a longitudinal collaborative project that monitors news output in 70 countries, reports that, despite the significant changes in the lives of women and their role in society over recent decades, their inclusion in the media agenda as news subjects, newsmakers and news producers is still strikingly lower than men.

This imbalance should not be attributed to gender discrimination but, rather, to the fact that there is a greater representation of men compared to women in this specific profession (Murtaza, 2012). However, when men are not the majority in an organization and there is gender discrimination among journalists, this imbalance is traced at both the horizontal and vertical levels. On the horizontal level of discrimination, media industries keep the roles of men and women distinct from one another, allocating women to lower-level 
positions in the organisation while, at the same time, assigning them specific roles (Gill, 2007). Even when both genders work in the same field, women tend to be placed in the lowest levels of the hierarchy, given that men occupy key managerial positions (Gill, 2007). On the level of vertical discrimination, salary differences between male and female journalists who work in the same positions can also be identified.

In the last 50 years, studies of the media or sociological studies of media organisations and news production have taken a variety of approaches (de Bruin, 2000); on one hand, there were older studies that dealt with the media without taking gender into account; and, on the other hand, there were newer studies focusing exclusively on gender-related aspects. The discourse that developed in the 1970s included important considerations regarding gender and organisational theory that enriched both ways of thinking (Gherardi, 2003).

In her study of social control in the newsroom, de Bruin (2000) acknowledged the difficulty of conforming to the corporate style and culture of an organisation. Her focus on interpersonal attitudes and group dynamics in the news organization highlight their influence in controlling the behaviour of people who work in the newsroom. Power, influence and control were treated as functions of the organisational hierarchy; however, the organisation itself, as a source of constraint, influence or definition of media production, was not the explicit focus of her analysis. Research on the immediate organisational work environment, the relationships among colleagues and the hierarchy in the media was at the core of academic work at the end of the 1960s and early '70s. During this period, research mostly focused on external social pressure (de Bruin, 2000). External pressure centred on the opinions of columnists and readers with respect to the content the organisation produced, and the pressure exerted on its employees was about focusing on specific content.

Until the late 1970s, most studies of media organisations did not present separate results for men and women (de Bruin, 2000). This was due to the fact that media organisation employees were treated as workers, as professionals; and gender was not taken into account with respect to the dynamics in media organisations (de Bruin, 2000). The discussion on the role of gender in news production and journalism focused primarily on the relationship between gender and professionalism, referring to the work practices of women in the newsroom or the presence of female journalists in it. The recent debate about gender representation in the media has also highlighted the gender dynamics that are developed within the organisation (de Bruin, 2000). The majority of studies based on the concept of gender and the media were done during the early 1990s - most often, with a title that was a variation of "women and the media" and, often, under the supervision of women, who contributed important information to the broader picture of what was going on in media organisations (Gill, 2007). The emphasis placed on studying the relationship among gender, journalism and news production focused on the interrelation between gender and professionalism. Another important strand in research addresses the topic of gender ste- 
reotyping in the media, which has been the most obvious finding in the discussion of the representation of women in the media.

It is a fact that, in the last 25 years, many organisations have tried, with varying degrees of success, to turn the workplace into a fairer and more accommodating place for women. Ely and Meyerson (2000) report that these attempts focused on various aspects of liberal feminist theory that, oddly enough, promote a limited view of both genders, which they considered responsible for the inability to achieve equality in organizations. More specifcally, liberal feminist theory does not succeed in refuting the widespread and deeply-rooted imbalance of power in social relationships between men and women. What liberal feminist theorists themselves note is that gender is perceived as a social process instituted in a series of organisational phenomena, formal policies and practices as well as informal standards of everyday interaction that seem to be gender-neutral (Ely \& Meyerson, 2000). Besides, they seem to indicate and maintain a gender-related process in which men and various forms of masculinity are dominant.

In his research on reporter and columnist preferences with respect to reporter decisionmaking, Joseph (1982) notes that female columnists are quite eager to pursue and maintain their professional role in order to make professional leaps in the organisation and climb the hierarchical ladder. In more recent studies, it is evident that men insist on labelling journalists based on their gender and treating their female colleagues more as females than equal professionals, thus inhibiting their professional development in the organisation. As de Bruin (2000) points out, journalism and femininity do not go well together in the eyes of men. A preferred topic of study has been the interaction of journalists in the newsroom, where women must work in a male-dominated culture in which professional identity and gender are at odds with one another (de Bruin, 2000). The situation has changed significantly over recent decades, moving away from a pattern in which female journalists are the exception rather than the rule in media organisations. A characteristic example is that of the well-known journalist Usha Rai, who was the first female columnist to feature in the Times of India in 1964 (Murtaza, 2012). Until that time, there were no women in the newsrooms, offices or typography departments of Indian newspapers; the only women at newspapers relegated to such duties as reception or telephone operators (Murtaza, 2012). During the 1970s and ' 80 s, the progress of women in media environments started to be studied more extensively, as reflected in UNESCO's cross-national study on women's employment, which reported on 239 companies in 43 countries (Gallagher, 1995). While a significant body of recent research (Neveu, 2000; Kaltenbrunner, Karsmasin \& Kraus, 2007; Uzule 2009; Djerf-Pierre, 2011) demonstrates increasing numbers of women working in the media sector, patterns of inequality reflected in underrepresentation, barriers to career development and wage imbalances are still dominant in the media sector (EIGE, 2013).

Interventions aiming at increasing the opportunities and skills that women need to compete effectively with men (such as education, policies against discrimination, work programmes for family expenses coverage and personal practices that acknowledge and 
reward traditional female skills) are not enough to resolve the 'gender issue' (de Bruin, 2000). Undoubtedly, there has been a marked improvement. However, much remains to be done, and critical issues still need to be addressed, such as equal access to leadership positions, decision-making centres, flexible working hours, maternity/paternity allowances, the issue of victimization and intimidation and a fairer representation of both genders in the news (Murtaza, 2012). These practices may be expanded, treating gender as a power axis. This requires members of the organisation to become involved in the attempt to expose and alter a whole set of organizational phenomena that, in obvious or covert ways, favour men. Even if the numbers of women in the profession have increased quite a lot and female journalists have made their mark in what was once considered a male-dominated sector, employers still do not realize that the better that working conditions are for women, the more beneficial this will prove for the organisation (Murtaza, 2012).

\section{Women and media in Greece and Cyprus}

Greece and Cyprus share specific common features as southern European countries when it comes to the positioning of women in society based on their geographical location and socioeconomic conditions. Over the past 40 years in Greece and only recently in Cyprus, there has been a transformation from a modern to a postmodern society. ${ }^{4}$ The traditional bipoles that characterized Greek society (e.g., tradition/modernisation, liberalism/populism, rationality/emotionality, individualism/communitarianism) have started to emerge in Cyprus during the last decade.

In this context, the preservation and reproduction of the structure of the family constitutes the primary mechanism for socialization and professional accomplishment in both countries. The reproduction of the traditional family's power is limited and only takes place to the extent that it succeeds in addressing modern customs and incorporating cultural changes and, more specifically, to the extent that it succeeds in managing the new-found liberties emphatically promoted by strong Western standards.

As noted by Vamvakas \& Panagiotopoulos (2010), an important change in the social position of women that took place in the 1980s was the acceptance of women's autonomy. Whether through radical feminism or state radicalism and institutional transformation, this decade brought about an acceptance of the capacity of women to provide high-quality labour in Greek organizations- in other words, there was a change in the nature of the labour provided by women, which freed women from their traditional roles in the household and transformed female labour into an autonomous career path.

Regarding the broadcasting landscape, the late 1980s (specifically, 1987) signalled the start of media deregulation in Greece (Tsevas, 1987; Zeri, 1996; Barboutis \& Klontzas, 2000; Gazi, 2005) and the emergence of privately-owned radio and television organisations. As noted by Gazi (2005), private radio and television stations established a new model of operation and organisation, and the people working for a media organisation had to conform 
to it. The aim of a privately-owned media organisation is profit. At the same time, stateowned radio and television stations retained their status as public organisations that do not participate in the intensely competitive capitalist market, which, according to Castells (1996), has become more and more ubiquitous and is based on the notion of networking and the informative capacity of information and communication technologies.

Cyprus has a similar structure in matters concerning the organisation of society but introduced private broadcasting in 1990 (Roussou, 2005; Vassiliadou, 2007; Sophocleus, 2008; Chrisanthou, 2008). As in Greece, privately-owned media organisations are founded on commercial power structures, and public broadcasting is regulated by the government. The reshaping of the media landscape in Cyprus occurred as a result of social change. At that time, the radio and television landscape was deregulated to comply with the European Economic Community and to support the request for full membership. The Republic of Cyprus applied for membership of the EEC in 1990. The abolition of the state monopoly in radio and television was also promoted as a demand of society, an indication that society in Cyprus had changed. The transition of Cyprus from a traditional to a modern society in which new values and behavioural patterns prevailed was becoming apparent. This shift has also greatly affected the media (Chrisanthou, 2008; Sophocleus, 2008).

\section{Methodology}

The present study builds on empirical data collected for Greece and Cyprus as part of a research project entitled "Advancing gender equality in decision-making in media organisations. Review of the implementation of the Beijing Platform for Action in the EU Member States", commissioned by the European Institute for Gender Equality and conducted in the $27 \mathrm{EU}$ member states and Croatia. Its aim was to identify the level of participation of women in decision-making positions as well as to explore the existence of internal genderequality policies, monitoring mechanisms and initiatives to support career development for women in the sector.

The research tools ${ }^{5}$ employed for the study were developed for the entire research group and consisted of:

1. A structured questionnaire containing information on the selected media organisations in Greece and Cyprus completed by the national researchers and organised around three main pillars: demographics, strategic and operational roles of employees, and equality policies, practices and approaches;

2. A structured questionnaire with gender-related equality developments completed by the national researchers containing information on national governmental policies and research, existing NGOs, monitoring organisations and unions and the activities of the national media industries in research and gender discrimination cases; and 
3. Semi-structured interviews with senior women media professionals ${ }^{6}$ concerning their working life and career experiences.

Moreover, an extensive literature review of the topic 'women and the media', including national reports, relevant research, policy briefs and commentaries, was also compiled and archived in English and other European languages. The purpose was to create a repository? of available texts that can be used as references in similar projects or studies.

The paper draws on data collected from structured questionnaires for the cases of Greece and Cyprus, the results of which were compared with the respective levels of the $27 \mathrm{EU}$ member states under study. It also derives data from the semi-structured interviews conducted with women journalists working in Greek and Cypriot media. The first questionnaire was completed with information obtained from the websites of the media organisations studied, their respective company profiles and annual reports, as well as information obtained through interviews with the executive staff of media organisations. The data set was enhanced by the second questionnaire, which focused on national legislation, governmental policies, professional associations and gender-related NGOs.

Data collection was carried out by national researchers in Greece and Cyprus, starting with the selection of media organisations that needed to be studied. The criteria for the selection of media organisations were the following: a. type of funding of the organisations (public or private), b. whether public-funded media organisations were the national broadcaster and c. the reach, audience figures, newspaper circulation and influence of public and private-funded media organisations (EIGE, 2013). In addition, the selection of private organisations was based on WACC's media-density index as well as on the knowledge and expertise of the national researchers regarding the particular national media context. In this way, we selected six media outlets, including two public-service broadcasters, two private broadcasters and two newspapers (see Table 1). The aim was to include a range of media organisations to form a sample that was not necessarily representative but informative and indicative of the Greek and Cypriot media landscape, which can provide data for comparison with other European countries.

\begin{tabular}{llll} 
Organisation & Type & Funding & Rationale \\
\hline Greece & & \\
\hline NET (New Greek Television) & Television \& Radio & Public & Public broadcaster \\
\hline MEGA CHANNEL & Television & Private & Largest private TV (audience share) \\
Kathimerini & Newspaper & Private & Most popular daily newspaper (circulation) \\
Cyprus & & & \\
\hline CYBC & Television \& Radio & Public & Public broadcaster \\
DIAS Media Group & Television \& Radio & Private & Largest private media organisation \\
\hline Phileleftheros LTD & Newspaper & Private & Most popular daily newspaper (circulation)
\end{tabular}

Table 1 


\section{Women on top?}

\section{An analysis of gender equality and policies in the media sector}

While female students in journalism and media outnumber their male colleagues in Greece to a great extent ( $80 \%$ and $20 \%$, respectively) with more balanced numbers in Cyprus (50\% and $50 \%$, respectively), following the EU average trend (Eurostat, 2010), the percentages drop significantly in the case of women professionals in the media sector. In Greece, only 28 percent of employees in programming and broadcasting activities are women. Though the number is a bit higher in Cyprus (38\%), the imbalance between women and men in the media sector remains striking. As is highlighted in the EIGE Report, "persistent patterns of inequality in the form of under-representation, glass-ceiling barriers to advancement and low pay (in relation to men) still remain firmly embedded within the media sector" (2013, p.16), a tendency that is apparent across the 28 countries under study. This contrast is also reflected in the recent study by the ILO (2014), which reports that certain audio-visual occupations remain largely the preserve of men while women dominate in stereotypical so-called 'feminine' professions related to make-up, clothes and hair.

The present study focuses on the case studies of Greece and Cyprus, comparing the resulting data with EU27 average figures and percentages. Our aim is to present the two countries that share common characteristics and features, as illustrated above, and to highlight their differences and similarities as European member states with the rest of the countries within the broader European context. Do both countries conform with EU policy regarding gender quality, or are they deeply influenced by country-specific characteristics that are the cause of a worrying regression in gender-sensitive issues? What is the relationship between gender and professionalism in both countries? What is the dynamic between gender and the organisation in Greece and Cyprus?

Starting with women in decision-making positions and on boards, we focus on the distinction between two levels of management structure, strategic (chief executive officer and board members) and operational (chief operating officer, other operational managers, heads of directorate/ unit and heads of department). The low representation of women in decision-making positions and on boards is apparent in both countries (see Graph 1), although Cyprus demonstrates higher percentages in both strategic (13\%) and operational (37\%) positions than Greece ( $13 \%$ and $30 \%$, respectively) and comes closer to the mean EU percentages when it comes to the operational level (33\%). While women appear to occupy positions at the operational level (almost one-third of total staff), their role is weaker on the strategic level.

While the modern era offers the individual the right to make decisions and choose freely their orientation in life - thus, promoting a modern individualism (Taylor, 1999) and abandoning traditional values and ideas that emphasise the preservation of the social hierarchy and the loss of personal freedom, gender still appears to be a decisive factor when it comes to career choices and opportunities. Media organisations seem to discourage the appointment of women to top management positions that shape their business strategy. 


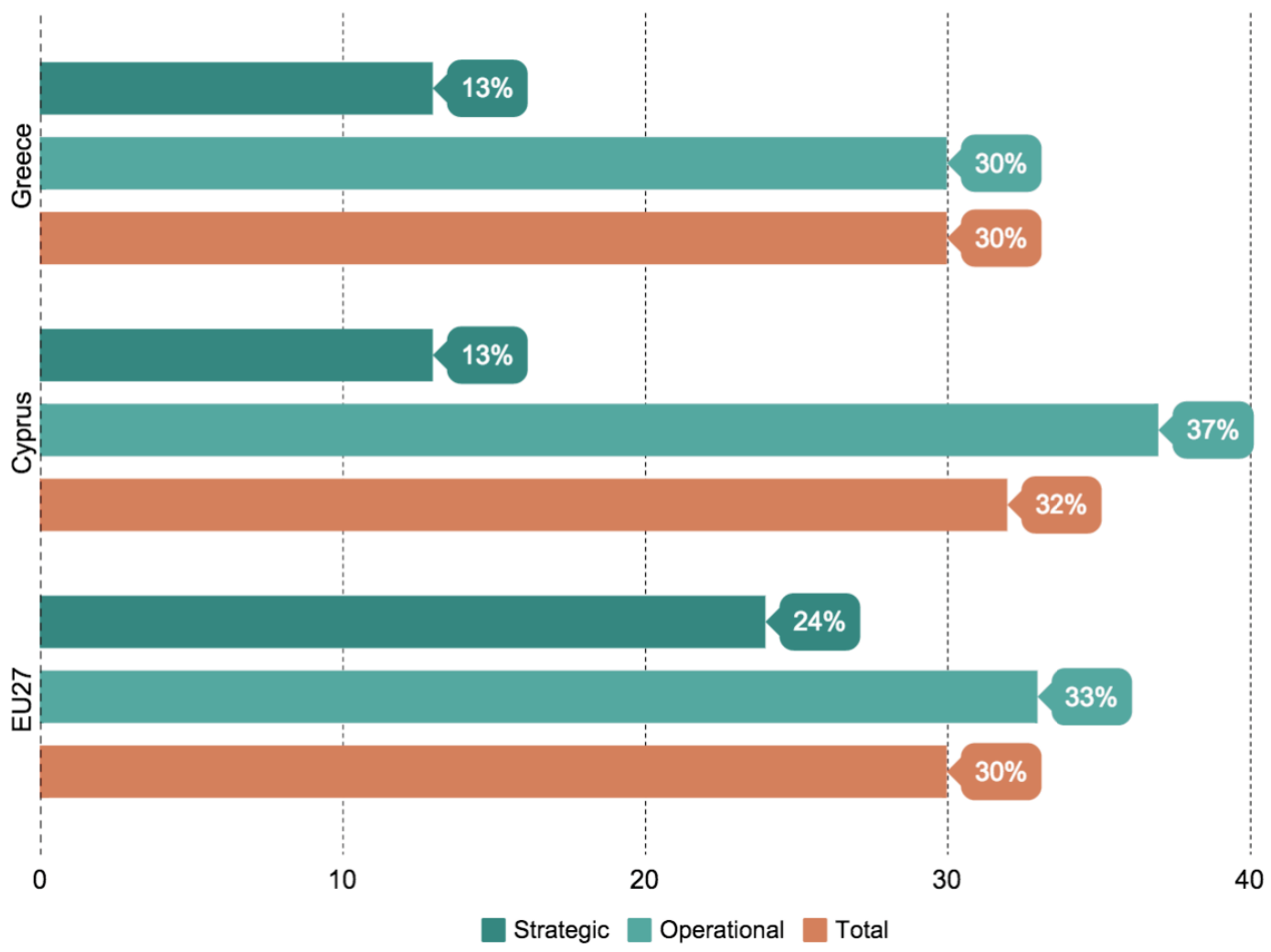

Graph 1. Women in decision-making positions on boards

In both countries, we observe the same trend: fewer women climb the hierarchical ladder in media organisations and occupy strategic decision-making posts. The findings from this study show that men are more likely to hold senior management positions associated with power and profit and that there continue to be barriers to women's career development and their access to decision-making positions in media industries:

Although you find a lot of women in media industries nowadays, they are not well educated, and there is always a tendency from your boss, who is always a man, to give them less interesting journalism issues. The political issues ... the political editor is usually a man. Very rare to find a woman. Very rare. You find a woman but not as many as men. So [it] is not so easy ... to get a promotion. (M.: public service chief editor, Cyprus)

The same view is shared by a Greek journalist working in public broadcasting:

In Greece, there were very few women who climbed the hierarchical ladder. Journalism has become a female profession, but the career development of a woman journalist is slower in relation to that of a man, I am afraid. This has nothing to do with qualifications but with the way the Greek society deals with women in public posts, let alone a woman journalist that influences public opinion. (N.: public broadcasting, chief editor, Greece) 
According to Settles (2004), many adults now take on multiple roles and belong to groups through which they construct their identities in an endless attempt to find meaning. A woman, for instance, can be a mother, wife, professional, union representative, etc. The ability to have multiple identities leads the person to develop a sense of individuality that provides multiple benefits and skills (Sieber, 1974; Marks, 1977; Barnett \& Baruch, 1985). However, despite the opportunities provided to people with multiple identities, top hierarchical positions are mostly occupied by men, and women climb the career ladder at a much slower pace when it comes to high-ranking positions in media organisations.

When we filter the results by sector and focus on the presence of women in top managerial levels in public media organisations (see Graph 2), we observe that the public sector offers more chances for women to be promoted to higher hierarchical positions. In Greece, the trend appears to be similar to the EU27 average on the operational level (26\% and $24 \%$, respectively), while the percentage drops to zero in the Cypriot case. Both Greece and Cyprus share the same level of promotion of women on the strategic level at eleven percent, significantly less than the EU27 average (29\%).

Our analysis follows the indicators developed by EIGE (2013, pp.7-11) by addressing decision-making directly - specifically, the sharing of high-ranking positions between women and men in media organisations as well as a review of gender equality policies that may be

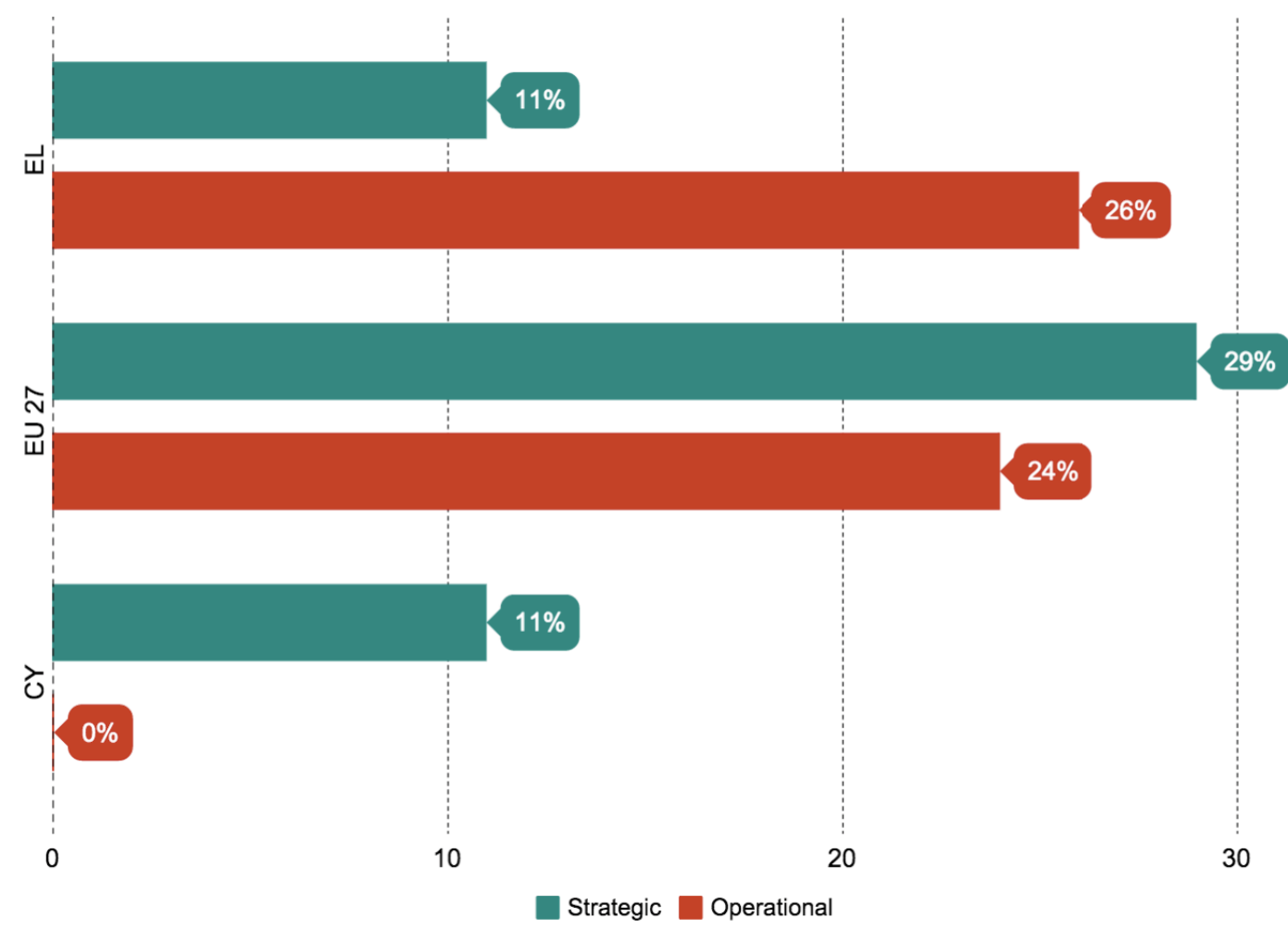

Graph 2. Women in decision-making positions/boards by public sector 
proposed or implemented by media organisations. The presence and dominance of men in the media business are clearly demonstrated in Table 2, which shows a deep gap between the two genders. The public organisations in both Greece and Cyprus promote women at 13 percent, much lower than the EU27 average (29\%). Private organisations in Greece show a striking gap between women and men working in media (6\% and $94 \%$, respectively), indicating a significant difference compared to the EU27. The situation in Cyprus is similar to EU27, though with $25 \%$ and $75 \%$, respectively.

\begin{tabular}{lrrrrrr} 
& \multicolumn{2}{c}{ Public \& private organisations } & \multicolumn{2}{c}{ Public organisations } & \multicolumn{2}{c}{ Private organisations } \\
\hline & Women & Men & Women & Men & Women & Men \\
\hline EL & $8 \%$ & $92 \%$ & $13 \%$ & $87 \%$ & $6 \%$ & $94 \%$ \\
EU 27 & $25 \%$ & $75 \%$ & $29 \%$ & $71 \%$ & $21 \%$ & $79 \%$ \\
CY & $17 \%$ & $83 \%$ & $13 \%$ & $87 \%$ & $25 \%$ & $75 \%$
\end{tabular}

Table 2

The inequality in the profession is clearly articulated by an editor-in-chief who works for a daily newspaper: "In a newsroom meeting, there are 15 people - 13 are men and two are women. There are no women directors in newspapers or in high-ranked positions. If they are not beautiful TV presenters on broadcasting channels, I rarely hear of women taking a top position in a media organisation. We are living in a man-dominant and deeply antifeministic society. There is no harmonisation with EU directives, no quotas, nothing [...] There is no encouragement or support to women who have children - it is very difficult for a woman to rise, there is no support at all." (P.: editor-in-chief, private newspaper)

When the public and private sectors are studied together, women in Greece (see Graph 3) occupy just eight percent of the decision-making bodies in comparison to 92 percent held by men. The situation looks a bit better in Cyprus (17\% women and $83 \%$ men, see Graph 4) and is similar to the average percentages in the EU27 (25\% and 75\%, respectively, see Graph 5). The public sector accommodates more women in decision-making positions than the private sector in Greece, Cyprus and the EU27. As already noted, the aim of the private sector is profit. At the same time, the public sectors in Greece (Gazi, 2005) and Cyprus retain their status as public organisations that do not participate in the intensely competitive capitalist market.

Despite women's non-negotiable presence in most professions in the labour market, their recruitment to senior positions in significant numbers in both the public and private sectors is still largely marginalized (Ross \& Carter, 2011); and, as our data indicate, the private sector is less encouraging for women seeking to occupy strategic and operational positions. Access to power remains directly connected to cultural views on gender-based differences in our society. Discussion and research on power management exercised by women has mainly focused on the study of discourse, social systems, organisations and 


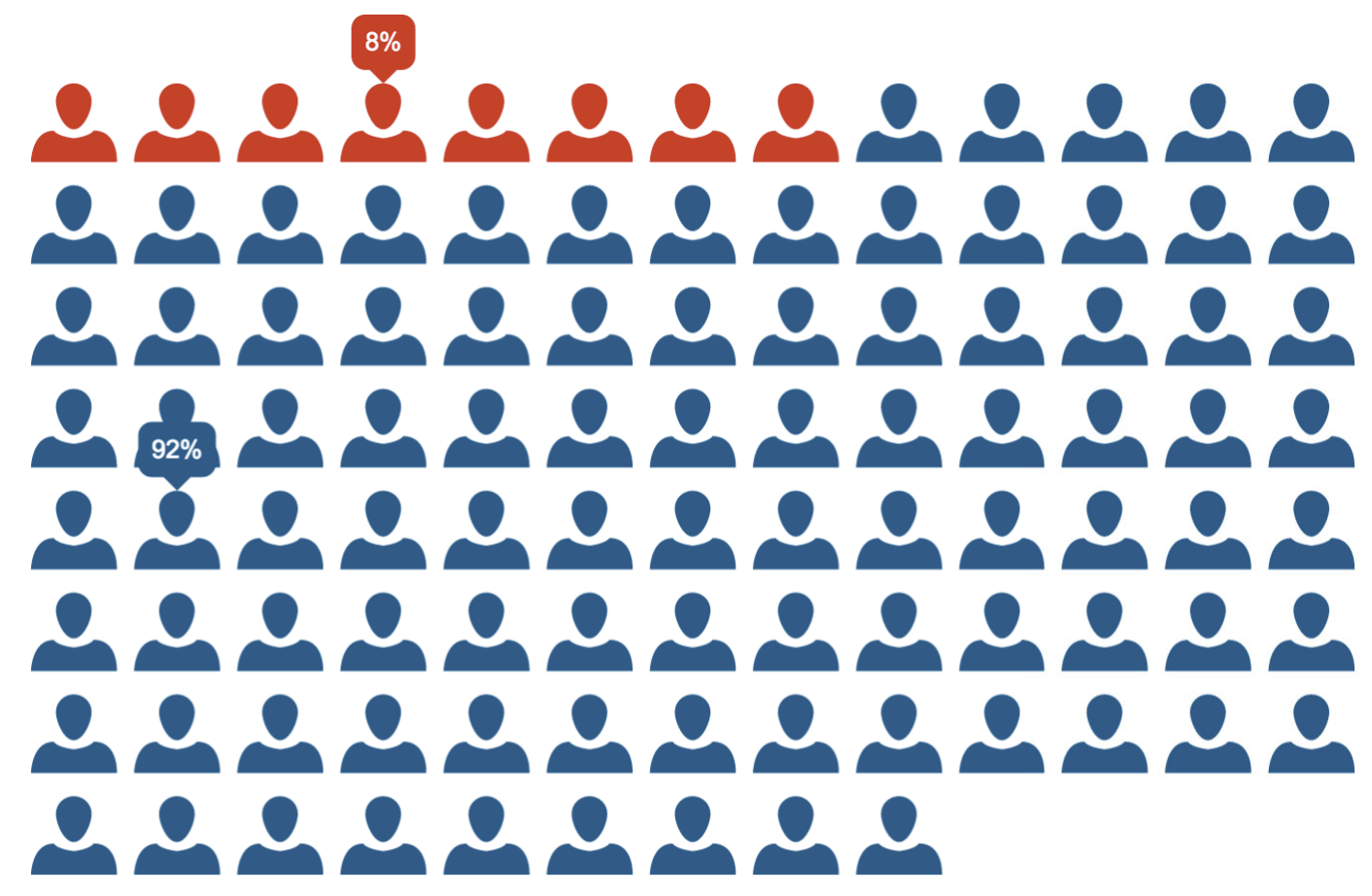

Women (8\%) Men (92\%)

Graph 3. Women \& men in decision-making bodies of public and private media (EL)

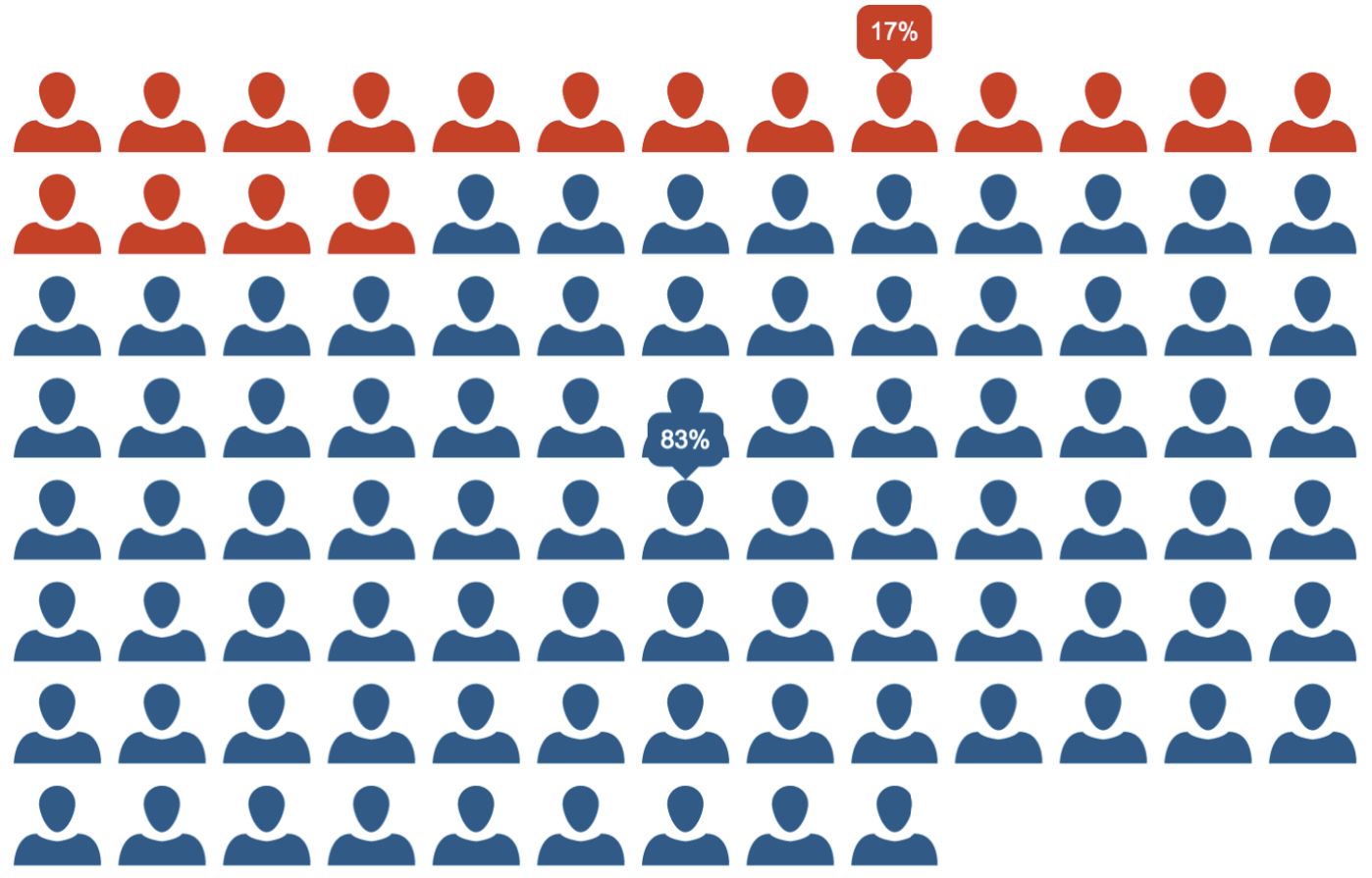

Women (17\%) Men (83\%)

Graph 4. Women \& men in decision-making bodies of public and private media (CY) 


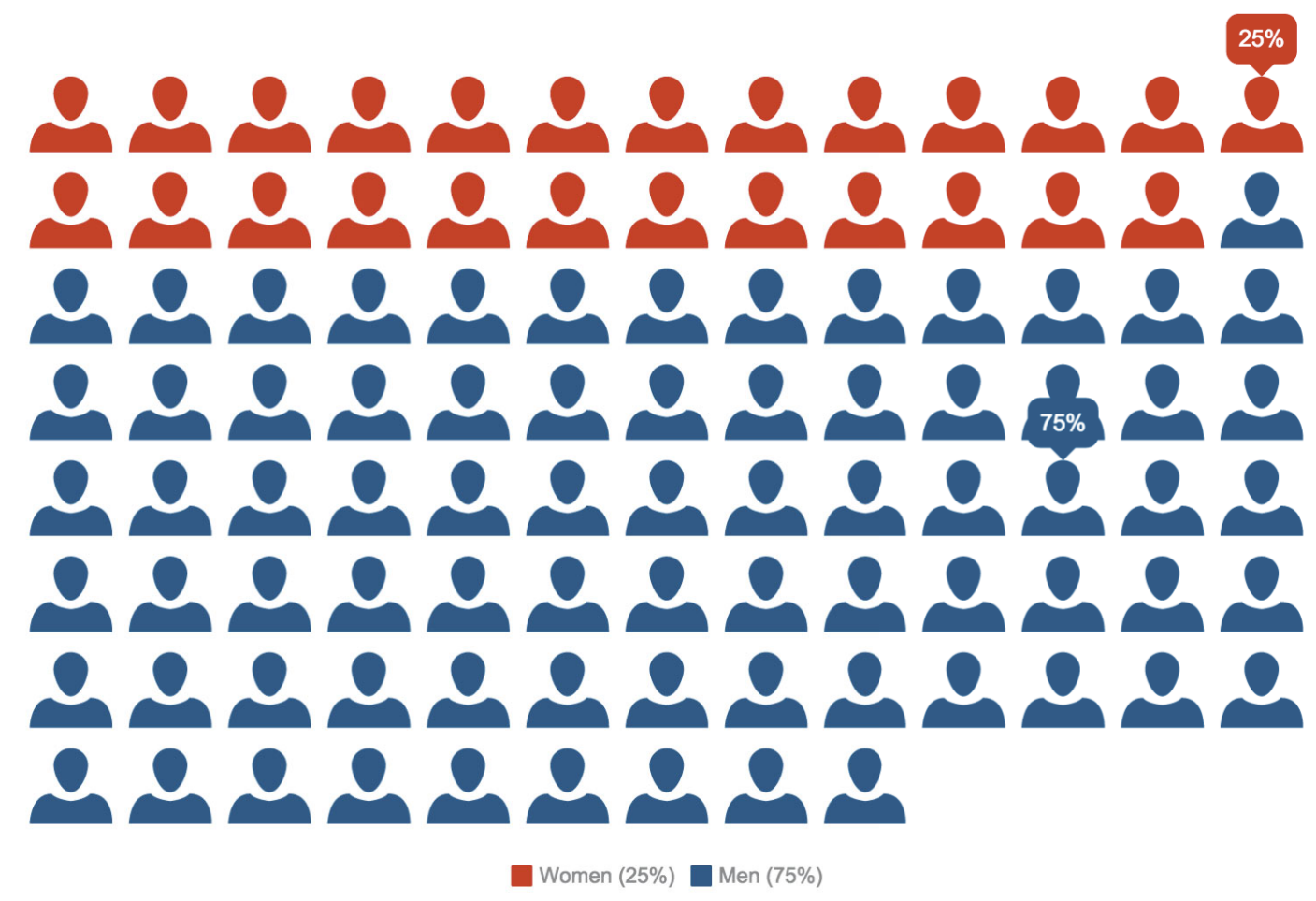

Graph 5. Women \& men in decision-making bodies of public \& private media (EU 27)

interpersonal communication (between men and women), emphasising the accumulation of resources that are necessary for exercising power.

The next indicator studied deals with the promotion policies for gender equality adopted by Greek and Cypriot media organisations. These policies may include genderequality plans, professional codes of conduct and strategic orientation that encourages gender equality and career advancement for women. Disappointingly, policies that promote gender in media organisations are completely absent from both Greece and Cyprus except for maternity leave in Cyprus (see Graph 6).

Apart from that, policies such as gender equality, equal opportunities or policies on diversity, dignity at work and paternity leave are absent from the organisations' strategic plans. Both countries appear to make no provision at all for addressing gender inequality issues at work and, especially, in the media sector. Measures that promote gender equality such as trainee positions or leadership training for women and equality awareness training for staff are also absent from the Greek and Cypriot media organisations studied (see Graph 7). The same lack of foresight policies for gender equality is noted in the case of bodies that are responsible for equality policy issues, harassment advisers, equality/diversity departments, equality/diversity officers, etc. (see Graph 8).

Social research reveals a persistent difference in favour of men when it comes to access to power. The processes relevant to the build-up of power differ for men and women, 
Article: "If you don't act, you are not going to get anything"

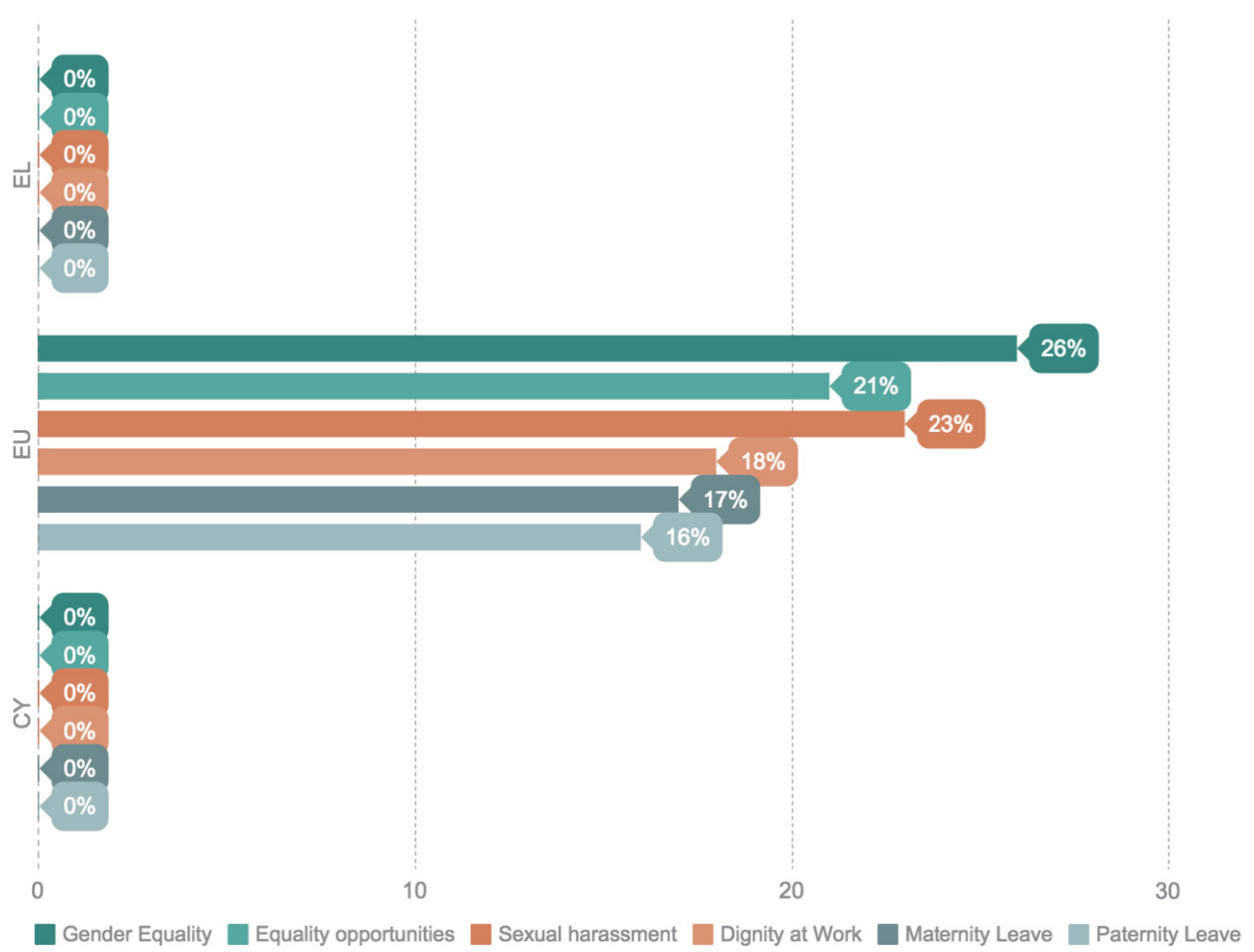

\section{Graph 6. Policies promoting gender equality}
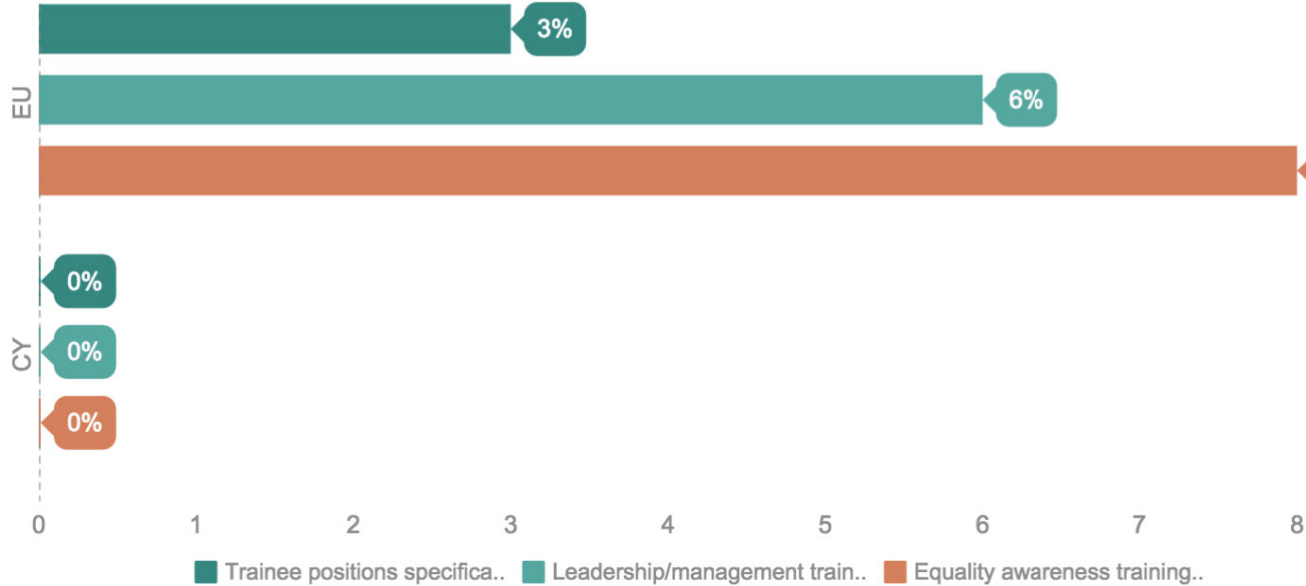

Graph 7. Measures promoting gender equality 


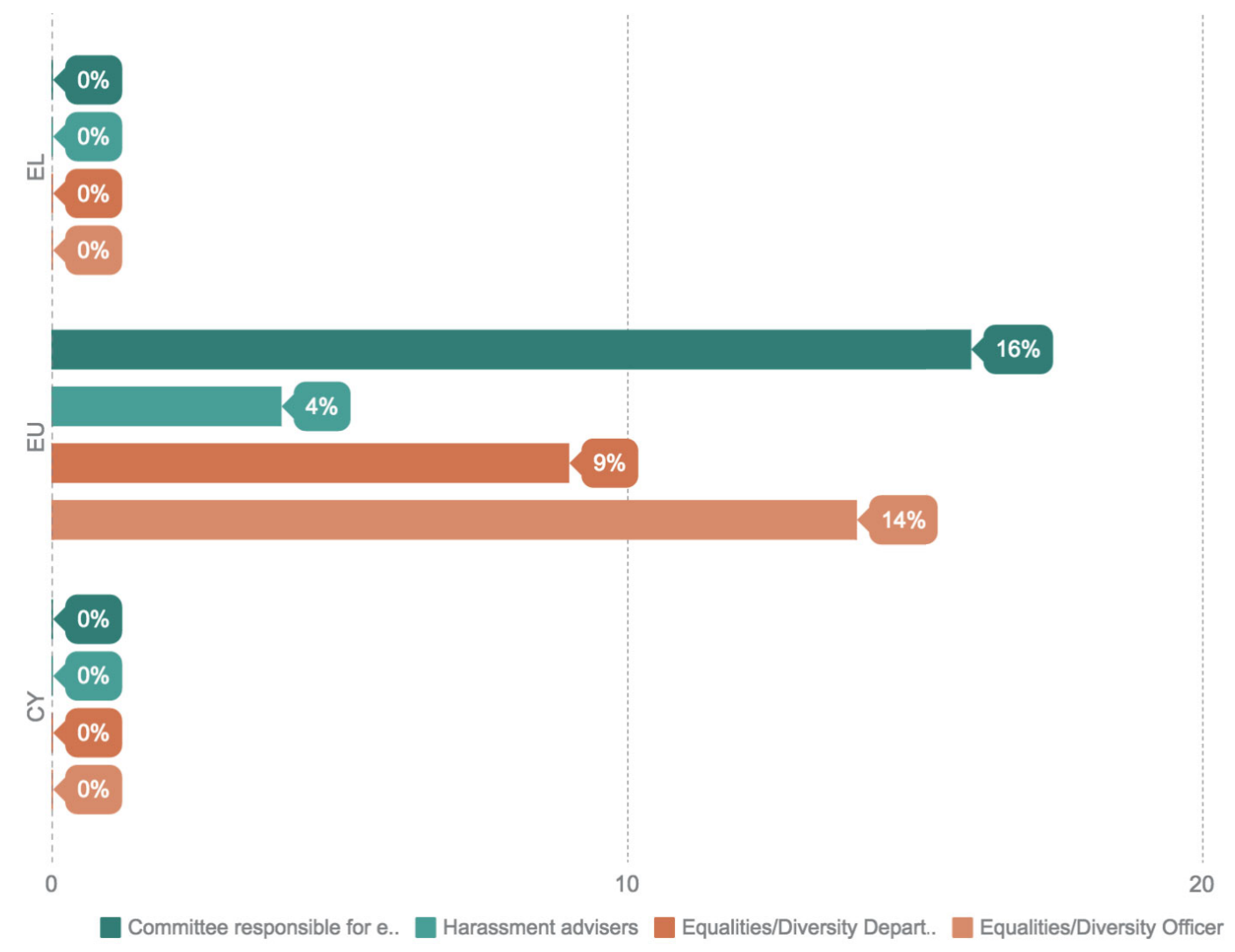

Graph 8. Bodies promoting gender equality

and the way to power seems to be full of obstacles for women. As our research demonstrates, the complete lack of support policies for gender equality as well as the limited access of women to leading managerial and operational positions in combination with a deeply-rooted stereotypical approach of media organisations, which still holds the journalistic profession to be a 'manly' business, create different working conditions for female and male media professionals. According to Simon (1958), March and Simon (1958), Crozier (1963, 1970), and adherents to theories of administrative behaviour, organisations consist of groups defined by the privileged control they exert over the strategic information necessary for the organisations in question or for other groups. In a media organisation, the administration, which is responsible for decision-making, maintains exclusive control over the information to be transmitted to the audience as well as the way in which decisions are made within that organisation.

Importantly, what many senior women made clear is that encouraging senior managers to take gender equality seriously is good for employees and, as recent studies on boardroom performance show, good for business. 
decided always by a man. Although I was more educated, I was very good in my job - I think - (laugh), I was doing my best, but there was always a man that had to decide for my promotion. So, I took a decision: I went to the court. I went to the court but, unfortunately, I had to deal with corrupted judges. Even though I had a strong case, the accused man had close ties with the judge and had also some support from the political parties. The result was that he managed to escape the accusations. I was disappointed about this. Very disappointed. But I believe...my belief is that, if you believe you are right, that you have the right to what you are doing, you have to demand it. You have to go and fight for your rights. You have to be a fighter." (M.: public service chief editor, Cyprus)

Albert \& Whetten (1985) note that professional identity is formed through a process that consists of comparisons and reflections within the context of an organisation. According to Barus-Michel (1997), organisations provide their members with certain privileged objects, surrogates of psychological objects that support them in the formation of their professional identity. However, it seems that women and men work under different conditions, which results in the formation of different professional identities. The third wave of feminism in the 1990s already acknowledged the variety inherent in the 'female' category and emphasised identity policies based on gender, race, nationality, social class and sexual preference (Mouffe, 1992). Even though many of the claims of the first (e.g., voting rights, property rights) and second (such as sexuality, family, workplace, reproductive rights) waves of feminism have been accepted in many Western societies, gender-related inequalities that are deeply rooted in the society continue to persist. As our results indicate, media organisations make almost no effort to promote working conditions that foster gender equality. The social groups that constitute an organisation follow their own special rules and designs and have certain sociocultural characteristics, such as gender.

\section{Striving for a gender-balanced professional identity}

We have defined professional identity as the identity formed in the context of an organisation, and we have underlined that, in postmodern societies, people tend to define their own identities by belonging to an organisation that integrates them in a network of social relations. However, problems and conflicts may be observed during identity formation due to the fact that the self belongs to and depends on communications systems outside his/ her control - and, consequently, success or failure is not only based on freedom of choice or creation but is also dependent on the sociocultural and financial situation.

There are several studies that support the view that professional identity is linked to the image the other creates of us. Dutton and Dukerich (1991) indicate that, if we wish to understand better the way in which organisations operate, we will have to investigate the direction in which persons (members of the organization) are looking - what they see and whether they like their reflection in the mirror or not.

The findings from this study show that sex-based discrimination constitutes a glassceiling image for professional identity that many women find hard to shatter. 
Several researchers posit that organisations are undergoing a crisis, placing obstacles to hinder their members' identity formation (Albert \& Whetten, 1985; Cheney \& Christensen, 2001). In addressing the issue of professional identity formation within modern media organisations, our research highlights the complex relationship between gender and identity development. As the literature demonstrates, organisations play a vital role in the construction of the professional identity and self-perception of working individuals. Since identity can be both externally and internally defined, others can become objects of violence for the subject (Busekist Von, 2004). According to Albert and Whetten (1985), breaking the link between internal and external definitions of identity in the context of the organisation can have consequences for the way identity is formed. As expected, the multiplicity of identities is linked to numerous negative psychological outcomes (Coverman, 1989; O'Driscoll, Ilgen \& Hildreth, 1992; Kossek \& Ozeki, 1998). This involvement may threaten a person's sense of self (Thoits, 1991) or result in a feeling of pressure that puts the person's available self-knowledge to the test (Fried et al., 1998). According to Barus-Michel,

if the person is going through a limited or prolonged period of crisis, if he/she no longer has the ability to use work as a means of expression, self-actualization, fight, recognition, satisfaction of his/her needs, then work becomes a destabilizing factor, rendering the person vulnerable to a point in which the crisis in the work environment is equated to the overall crisis the person is going through as a subject and active social entity (1997, p.53).

Although there is a strong presence of women in journalism education and newsrooms, the situation looks rather bleak when it comes to tracking their appointment to high-ranking positions, (see EIGE, 2013); and this is not limited to the two countries studied, Greece and Cyprus. Gender inequality is apparent not only at the higher levels of media professionals but also in media coverage (see WACC 2005, 2010). Though a slow process of change is visible, there are still organisational cultures and structures that constrain the promotion of women to decision-making positions. This is a challenge not only for professional media organisations and associations but also for national media regulatory bodies, national and EU policy makers and legislators. Though women have achieved great progress in positioning themselves within the societies and establishing a series of rights connected with the first waves of feminism, there is still a deep and often overlooked gender gap when it comes to challenging long-established hierarchies. Echoing Nancy Fraser (2015) in her interview with Gary Gutting,

feminism is not simply a matter of getting a smattering of individual women into positions of power and privilege within existing social hierarchies. It is rather about overcoming those hierarchies. This requires challenging the structural sources of gender domination in capitalist society [...]. There can be no 'emancipation of women' so long as this structure remains intact. 
Article: "If you don't act, you are not going to get anything"

\section{Notes}

1 The Beijing Declaration and Platform for Action for Equality, Development and Peace (BPfA) was officially adopted at the Fourth World Conference on Women, held in Beijing in 1995. The BPfA is a programme for action to promote and protect the human rights of women and girls, reaffirming these rights as an inalienable, integral and indivisible part of universal human rights. 'Women and the media' is one of 12 critical areas of concern for the BPfA (see Findings, 4 and also http://www.un.org/womenwatch/daw/beijing/platform).

2 The project was coordinated by loana Borza (EIGE) together with Prof. Karen Ross (Project Manager) and Prof. Claudia Padovani (Senior Researcher). Prof. Karen Ross (University of Liverpool), Prof. Claudia Padovani (University of Padova) and Dr. Erzsébet Barát (University of Szeged) were the regional coordinators, supported by Dr. Monia Azzalini (Osservatorio di Pavia Media Research).

3 Greek origin. Osmosis: Process of gradual or unconscious assimilation of ideas, knowledge etc. (Oxford Dictionary).

4 There is a noted transition towards a mass-individualistic society, social pluralism, changing social relations, and challenged traditional social structures. At the same time, the family-centric Mediterranean model has been adjusted due to the massive entry of women into education and the labour market (Vamvakas \& Panagiotopoulos, 2010).

5 The questionnaires are available as appendices in Report, $88 \mathrm{ff}$.

6 Senior media professionals included editors-in-chief, heads of department or board members/CEOs.

7 See http://womenandmedia.eu/resources/eu-bibliography.

\section{References}

Albert, S. \& Whetten, D.A. (1985). Organizational identity. Research in Organizational Behavior, 7, 263-295. Allan, S. (2010). News Culture. Maidenhead: Open University Press.

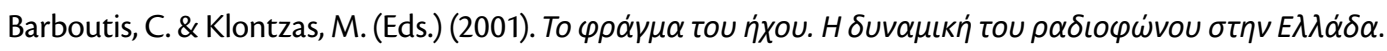
AӨńva: Патаһńon. [In Greek]

Barnett, R.C. \& Baruch, G.K. (1985). Women's involvement in multiple roles and psychological distress. Journal of Personality and Social Psychology, 49, 135-145.

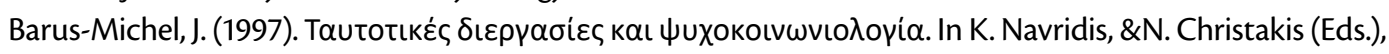

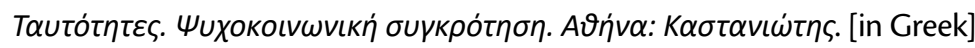

Busekist Von, A. (2004). Uses and misuses of the concept of identity, Security Dialogue, 35(1), 81-98.

Byerly, C.M. (2011). Global Report on the Status of Women in News Media (Technical Report). Washington DC: International Women's Media Foundation.

Castells, M. (1996). The Rise of the Network Society. Oxford: Blackwell.

Cheney, G. \& Christensen, L.T. (2001). Organizational identity at issue: Linkages between 'internal' and 'external' organizational communication. In F.M. Jablin \& L.L. Putnam (Eds.) New Handbook of Organizational Communication (pp. 231-269). Newbury Park, CA: Sage.

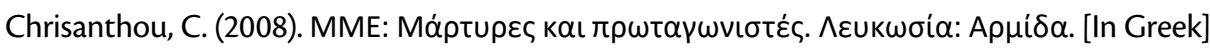

Coverman, S. (1989). Role overload, role conflict, and stress: Addressing consequences of multiple role demands. Social Forces, 67(4), 965-982.

Crozier, M. (1963). Le phénomène bureaucratique, Seuil, Paris.Crozier, M. (1970). La société bloquée, Seuil, Paris.

De Bruin, M. and Ross, K. (Eds.) (2004). Gender and Newsroom Practice. Cresskill, NJ: Hampton Press. 
De Bruin, M. (2000). Gender, organizational and professional identities in journalism. Journalism, 1(2), 217238.

Djerf-Pierre M. (2011). The difference engine: Gender equality, journalism and the good society. Feminist Media Studies, 11(1), 43-51.

Djerf-Pierre, M. (2005). Lonely at the top: gendered media elites in Sweden. Journalism, 6(3), 265-290.

Dutton, J. \& Dukerich, J. (1991). Keeping an eye on the mirror: Image and identity in organizational adaptation. Academy of Management Journal, 34, 517-554.

EIGE, European Institute of Gender Equality (2013). Review of the Implementation of the Beijing Platform for Action in the EU Member States: Women and the Media - Advancing Gender Equality in DecisionMaking in Media Organizations. Luxembourg: Publications Office of the European Union.

Ely, J.R., Stone, P., Ammerman, C. (2014). Rethink what you "know" about high-achieving women. Harvard Business Review 92, no. 12 (December issue, 101-109.

Ely, J.R., \& Meyerson, D.E. (2000). Advancing gender equity in organizations: The challenge and importance of maintaining a gender narrative. Organization, 7, 589-608.Eurostat (2010). LFS (Ifsa_egan2; Ifsa_ egan22d).

Fraser, N. (2015, 15 October). A feminism where 'lean in' means leaning on othes. The New York Times, Recovered 10/15: http://opinionator.blogs.nytimes.com/2015/10/15/a-feminism-where-leaning-inmeans-leaning-on-others/?smid=fb-share\&_r=1.

Fried, Y., Ben-David, H.A., Tiegs, R.B., Avital, N., \& Yeverechyahu, U. (1998). The interactive effect of role conflict and role ambiguity on job performance, Journal of Occupational and Organizational Psychology, 71, 19-27.

Gallagher, M. (in collaboration with Euler, M. v.) (1995). An unfinished story: Gender patterns in media employment, Reports and papers on mass communication no 110, Paris: UNESCO Publishing.

Gazi, A. (2005). Identity Construction of the Music Radio Producer. PhD thesis. Athens: National and Kapodistrian University of Athens.

Gherardi, S. (2003). Feminist theory and organization theory: A dialogue on new bases. In H.H. Tsoukas, \& C. Knudsen (Eds.), The Oxford Handbook of Organization Theory: Metatheoritical Perspectives (pp. 210236). Oxford: Oxford University Press.

Gill, R. (2007). Gender and the Media. Cambridge: Polity.Gioia, D.A. (1998). From individual to organizational identity. In D. Whetten, \& P. Godfrey (Eds.), Identity in Organizations. Building Theory through Conversations (pp. 17-31). Thousand Oaks, CA: Sage.

International Federation of Journalists (2001). Equality and quality: Setting standards for women in journalism. IFJ Survey on the Status of Women Journalists. Brussels: IFJ. http://www.iff.org/assets/docs/231/007/ a61e5e7-2c52b07.pdf.

Joseph, T. (1982). Reporters' and editors' preferences toward reporter decision-making. Journalism Quarterly, 59, 219-248.

Kaltenbrunner A., Karmasin M., \& Draus D. (Eds.) (2007). Der journalisten-report 1. Osterreichs Medien un ihre Macher. Eine empirische Erhebung, Facultas Wien.

Kossek, E.E., \& Ozeki, C. (1998). Work-family conflict, policies, and the job-life satisfaction relationship: A review and directions for organizational behavior-human resources research. Journal of Applied Psychology, 83(2).

Marcellus, J. (2005). Bo's'n's whistle: Representing “Rosie the Riveter" on the job. American Journalism, 22(2), 83-108.

March, J.G., \& Simon, H. (1958). Organizations. Paris: Blackwell.

Marks, S.R. (1977). Multiple roles and role strain: Some notes on human energy, time and commitment, American Sociological Review, 42, 921-936. 
Muffe, C. (1992). Dimensions of radical democracy: Pluralism, citizenship, community. London: Verso.

Murtaza, S. (2012). Understanding Women's Issues - A Feminist Standpoint. Germany: Lambert Academic Publications.

Neveu E. (2000). Le genre du journalisme. Des ambivalences de la féminisation d'une profession. Politix, 13(51), 179-212.

O'Driscoll, M.P., llgen, D.R., \& Hildreth, K. (1992). Time devoted to job and off-job activities, interrole conflict, and affective experiences. Journal of Applied Psychology, 77(3), 272-279.

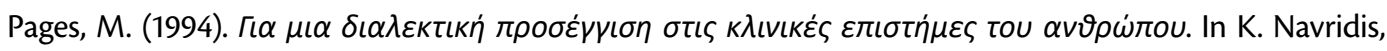

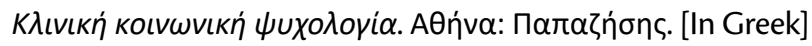

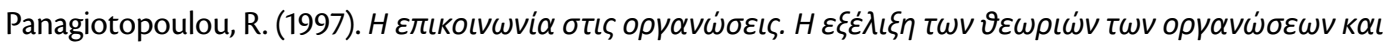

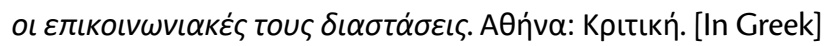

Ross, K., \& Carter, C. (2011). Women and news: A long and winding road. Media, Culture \& Society, 33(8), 1148-1165.

Roussou, N. (2005). Cyprus. Newspapers: Print news and their online twins. In R. Van der Wurff, \& E. Lauf (Eds.), Print and Online Newspapers in Europe (pp. 145-157). Amsterdam: Het Spinuis.

Settles, I. (2004). When multiple identities interfere: The role of identity centrality. Society for Personality and Social Psychology, 30(4), 487-500.

Sieber, S.D. (1974). Toward a theory of role accumulation. American Sociological Review, 39, 567-578.

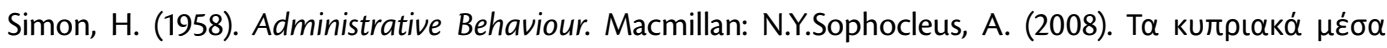

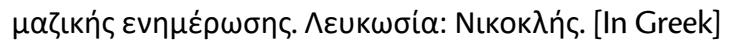

Strati, A. (1989). Aesthetics and organizational skill. In Turner, B. Organizational Symbolism. Berlin: de Gruyter.

Taylor, C. (1999), The malaises of modernity and the moral sources of the self. Philosophy \& Social Criticism, 25(3), 29-55.

Thoits, P.A. (1991). On merging identity theory and stress research, Social Psychology Quarterly, 54(2), 101112.

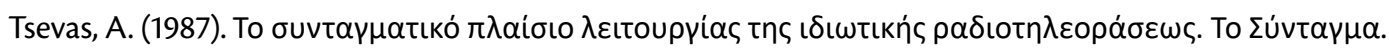
[In Greek]

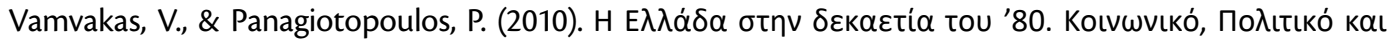

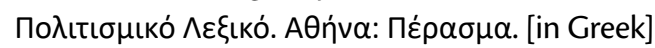

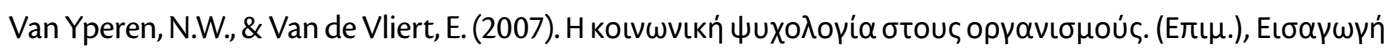

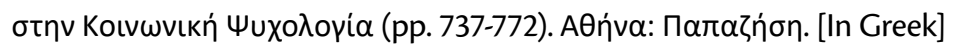

Vassiliadou, M. (2007). The Cypriot media landscape. In Terzis, G. (Ed.), European Media Governance: National and Regional Dimensions (pp. 201-212). Bristol: Intellect.

Witkin, R.W. (1989). The collusive manoeuvre: A study of organizational style in work relations. In B. Turner, Organizational Symbolism, Berlin: de Gruyter.

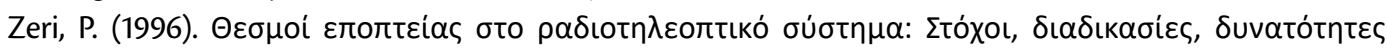

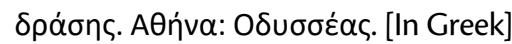


Article: "If you don't act, you are not going to get anything"

Angeliki Gazi

Assistant Professor

Department of Communication and Internet Studies

Cyprus University of Technology, Cyprus

angeliki.gazi@cut.ac.cy

Dimitra Dimitrakopoulou

Assistant Professor

School of Journalism \& Mass Communication

Aristotle University of Thessaloniki, Greece

dimitrakopouloud@jour.auth.gr 